\title{
INDÍGENAS SOB UM CONTEXTO VULNERÁ VEL DE SEGURIDADE SOCIAL EM MEIO À CRISE SANITÁRIA
}

\author{
Bruno Lopes Ninomiya ${ }^{1}$ \\ Isabella Coimbra Peixoto ${ }^{2}$ \\ Lucas De Carvalho Pereira Da Silva ${ }^{3}$ \\ Adilson José Moreira ${ }^{4}$
}

\section{RESUMO}

Objetivo: Analisar, desde uma perspectiva histórica, os processos geradores de vulnerabilidade do grupo indígena consoante à pandemia causada pelo coronavírus. Metodologia: Efetuou-se uma revisão bibliográfica em artigos e livros que tratassem da questão da vulnerabilidade e discriminação enfrentada pelas tribos indígenas, alinhada a uma análise quanto a falta de reconhecimento social, político e cultural do grupo em questão; assim como uma pequena pesquisa jurisprudencial. Resultados: Constatou-se que o problema histórico de opressão e vulnerabilidade dos indígenas ratifica um processo, em curso, de genocídio, e sua existência e proteção correm risco durante a crise sanitária. Com isso, faz-se necessário uma transformação cultural, com o objetivo da valorização e integração das diferentes culturas indígenas na política. Contribuições: O estudo histórico demonstra a estrutura de violência que impôs aos indígenas suas condições vulneráveis e que se mostra de forma intensa durante a pandemia causada pelo novo coronavírus, realçando ainda mais o descaso por parte do Estado em relação a esse grupo.

Palavras-Chave: Vulnerabilidade; Indígenas; Corona vírus; Sistema internacionalde Direitos Huma nos; Justiça .

Submetido em: 12/02/2021

Aprovado em: 28/05/2021

DOI: https://doi.org/10.37497/revcampojur.v9i1.676

\footnotetext{
1 Graduando em direito pela Universidade Presbiteriana Mackenzie (UPM). Pesquisador do Núcleo de Direito e Descolonização (USJT/CNPq) e do Laboratório de Pesquisa em Sociologia Jurídica (UPM). Bolsista de iniciação científica pelo MackPesquisa. Orcid id: https://orcid.org/0000-0002-4323-4443.E-mail: blopesn@hotmail.com

2 Graduanda em direito pela Universidade Presbiteriana Mackenzie (UPM). Orcid id: https://orcid.org/0000-00023787-5383. E-mail: isabellacpeixoto@outlook.com

${ }^{3}$ Graduando em direito pela Universidade Presbiteriana Mackenzie (UPM). Orcid id: https://orcid.org/0000-00021775-0188. E-mail: lucas-carvalho_silva@live.com

4 Doutor em Direito pela Universidade de Harvard (2013), Doutor em Direito Constitucional pela UFMG (2007), Mestre em Direito pela Universidade de Harvard (2005) e Bacharel em Direito pela UFMG (1999). Professor na Faculdade de Direito da Universidade Presbiteriana Mackenzie (São Paulo, SP, Brasil). Orcid id: https://orcid.org/0000-0002-0489-5011.E-mail: ajmoreirabh@gmail.com
} 


\title{
INDIGENOUS PEOPLE IN A VULNERABLE SOCIAL SECURITY CONTEXT AMIDST THE SANITARY CRISIS
}

\begin{abstract}
Objective: Analyze, from the historical perspective, how the vulnerability of the indigenous group was generated due to the pandemic caused by the new coronavirus. Methodology: A bibliographic review was conducted based on papers and books concerning the vulnerability and discrimination faced by the indigenous tribes; as well as a study about the lack of social, political and cultural recognition of the group; and a brief jurisprudence research. Results: It was concluded that the historical problem of oppression and vulnerability from the indigenous confirm an ongoing processes of genocide, and their existence and protection are in danger during this pandemic. Thus, a cultural transformation is necessary, with the objective of valuing and integrating different indigenous cultures in politics. Contributions: The historical study demonstrates the violence structure which imposed vulnerable conditions to the indigenous peoples which were highlighted due to the pandemic, enhancing even more the government's disregard for them.
\end{abstract}

Keywords: Vulnerability; Indigenous; Coronavirus; International system of human rights; Justice.

\section{INTRODUÇÃO}

Soa oportuno iniciar esse artigo elucidando a importância de se atentar aos indígenas ante a sua vulnerabilidade diante da crise sanitária que vivemos no Brasil. Segundo o SESAI (Secretaria Especial de Saúde Indígena), são 2.7334 casos confirmados de coronavírus entre os povos indígenas, com o total de 433 óbitos e, levando em conta ind ígenas em um contexto urbano, o número de óbitos sobe para 826 (BOLETIM EPIDEMIOLÓGICODA SESAI, 2020).

É indispensável compreender que a vulnerabilidade indigena não é apenas causada pelo vírus da Covid-19, mas também por um processo de opressão histórica constante em relação à invasão de seu território (GOODALE, 2006; GALEANO, 2010; TUCK; YANG, 2012; APURINÃ; SCANDOLA, 2020; GONZAGA, 2021). Dessa forma, procuramos enfatizar a importância do devido reconhecimento dos indígenas como representantes políticos, respeito às suas tradições culturais e o devido reconhecimento de suas terras.

Para se falar de vulnerabilidade, precisamos primeiro entender o que são os grupos minoritários e a diferenciação dos dois conceitos. Sob o prisma da sociologia entendemos por minoria aqueles indivíduos que são diferenciados da maioria da sociedade, possuindo pouca representatividade política e econômica, independente de seu valor numérico em relação à

Campo Jurídico|Barreiras (BA) | v.9 |e676| p.01-34 |Janeiro-Junho|2021 
socied ade total (MOREIRA, 2020). Dentre eles estão os negros, os homossexuais, as mulheres, os índios, os transgêneros, entre outros.

A vulnerabilidade social é uma condição de fragilidade, podendo ser tanto material como moral, em indivíduos ou um grupo de risco em um contexto econômico-social. Estão sujeitos à vulnerabilidade os grupos minoritários, pois estes possuem sua participação a oportunidades dificultada ou até mesmo vetada em razão de uma sociedade extremamente elitista, que se encontra atualmente padronizada por homens brancos e heterossexuais (BERGSTRAND, 2015; MOREIRA, 2019).

Elida Séguin, abordando o assunto em uma perspectiva jurídica, descreve que os grupos minoritários e os grupos vulneráveis possuem uma similaridade em seus elementos, contudo não apresentam necessariamente uma relação de proximidade conceitual. A similaridade se dá no afetamento que ambos sofrem ao se encontrarem em um contexto onde seu poder é retirado, sendo eles, portanto, "dominados" em relação aos outros. Em consequência, ocorre uma marginalização perante seus costumes, além de uma constante violência moral, psicológica e física (SÉGUIN, 2002).

O jornalista Muniz Sodré de Araújo Cabral aborda um importante tema referente à democracia representativa, onde explicita que um dos preceitos da democracia representativa sempre prevalecerá à vontade da maioria, pois é somente com esse processo que ela poderá ser ouvida. Sendo assim, evidencia-se, na visão de Sodré (2005, p. 11), que a minoria é qualitativa, por ser responsável pelo processo de transformação e moção: "minoria não é, portanto, uma fusão gregária mobilizadora, como a massa ou a multidão ou ainda um grupo, mas principalmente um dispositivo simbólico com uma intencionalidade ético-política dentro da luta contra-hegemônica".

Desde a invasão no Brasil pelos portugueses, os indígenas se viram sem sua devida representatividade, preservação e demarcação territorial (LOBO, 1996; BARRETO, 2003; VILLARES, 2009). Esse processo perdura até hoje, mesmo com a adoção de políticas públicas que visam protegê-los dessa opressão (CUNHA; BARBOSA, 2018). Além de serem um grupo minoritário, em diversos contextos eles se encontram em uma situação de vulnerabilidade extrínseca, onde as circunstâncias externas - aquelas fora de seu controle - acabam colocando seu povo em uma situação vulnerável, send o o caso da crise sanitária que o mund o está sofrendo atualmente (OLIVEIRA FILHO, 2000).

Campo Jurídico|Barreiras (BA) | v.9 |e676| p.01-34 |Janeiro-Junho|2021 
Uma alta parcela da população indigena pode sofrer impactos fortíssimos em razão da alta transmissibilidade do coronavírus, principalmente pelo seu contexto de vulnerabilidade social relacionado a pessoas que vêm de centros urbanos e invadem os espaços indígenas, podendo contaminá-los e disseminar a doença para demais tribos. $\mathrm{O}$ fator da limitação relacionado a uma assistência médica e logística do transporte de enfermos também são condições que deixam esse grupo mais suscetível à vulnerabilidade. Com essa fragilização, além de uma mortalidade crescente que esses povos vêm sofrendo, há um impacto direto da sua integridade socioeconômica, o que dificulta ainda mais em lidarem com as faltas de políticas públicas relacionadas a sua proteção territorial (APURINÃ; SCANDOLA, 2020)..

Diante dessa indignação, o presente ensaio pretende analisar, desde uma perspectiva histórica, os processos geradores de vulnerabilidade do grupo indígena consoante à pandemia causada pelo coronavírus. Efetuou-se uma revisão bibliográfica em artigos e livros que tratassem da questão da vulnerabilidade e discriminação enfrentada pelas tribos indígenas, alinhada a uma análise quanto a falta de reconhecimento social, político e cultural do grupo em questão; assim como uma pequena pesquisa jurisprudencial.

Desse modo, dividimos o artigo em sete partes, além da introdução e conclusão. Em um primeiro momento realizou-se um estudo histórico para compreender de que forma a vulnerabilidade indígena foi formada. Em um segundo momento demonstramos as dimensões da discriminação dos indígenas. Em um terceiro momento realçamos, brevemente, da falta de representatividade indígena na política. Em um quarto momento tratamos dos perigos da exposição das tribos indígenas ao vírus. Em um quinto momento fizemos uma reflexão acerca da necessidade de uma reinterpretação do papel do Estado quanto as questões indígenas. Em um sexto momento realizamos um paralelo entre a situação vulnerável dos indígenas com as teorias da professora Nancy Fraser. Em um sétimo e último momento analisamos a suposta aplicabilid ade do sistema internacional de direitos humanos com as negligências e ações estatais brasileiras.

\section{HERANÇA COLONIAL: A VULNERABILIDADE COMOPROCESSO HISTÓRICO}

A ideia de vulnerabilidade presente neste ponto deve ser abordada em conjunto com a construção histórica do grupo minoritário que será analisado. As comunidades indígenas se enquadram dentro de um grupo minoritário extremamente vulnerável no contexto de pandemia

Campo Jurídico|Barreiras (BA) | v.9 |e676| p.01-34 |Janeiro-Junho|2021 
e, para entender o motivo, é necessário observar os antecedentes, partindo da colonização para entend ercomo certos valores se tornaram enraizad os na sociedade brasileira e de como os povos originários são tratados (ALCÂNTARA; MAIA; TINÔNOCO, 2018; MANTELLI; ALMEIDA, 2019).

Este ponto passará de 1500 até 1985, já a questão que envolve a nova República será abordada em outro tópico.

O processo de genocídio do povo nativo entrou em curso no ano de $1500 \mathrm{com}$ a chegada dos europeus ao que hoje é conhecid o como Brasil. No período da chegada, estima-se que viviam aproximadamente 3 milhões de pessoas no território. Em seguida, geraram-se confrontos entre os nativos e os europeus, os quais também trouxeram novas doenças. Assim, a partir desse processo de colonização, a população foi reduzida drasticamente (GALEANO, 2010).

Dados publicados pela FUNAI (Fundação Nacional do Índio) indicam que desde 1500 até a década de 1970 a população indígena brasileira sofreu um grande declínio e, muitos povos foram extintos. Consequentemente, com o desaparecimento desses indivíduos, perderam-se a língua e a história de um povo.

\subsection{PERÍODO COLONIAL}

Não havia dentro da colônia nenhuma legislação própria para os indígenas, aliás, o ordenamento jurídico utilizado não era um próprio do Brasil. Toda a fonte do Direito brasileiro emanava da metrópole, no caso as Ordenações Manuelinas e, a partir de 1603, as Ordenações Filipinas (VIEIRA, 2015). Não sendo reconhecido nenhum direito aos indígenas, estes ficaram à mercê de todo tipo de violação e isso contribuiu para dar início ao processo de genocídio no primeiro século de colonização.

Mesmo que supostamente os índios tivessem alguma espécie de direito reconhecido, poderia acontecer a escravização deles em caso de guerra justa, ou seja, sob a justificativa certa os indígenas poderiam ser escravizados dentro da, suposta, legalidade.

Campo Jurídico|Barreiras (BA) | v.9 |e676| p.01-34 |Janeiro-Junho|2021 


\subsection{PERÍODO IMPERIAL}

No que tange aos direitos dos indígenas, o período imperial apresentou um retrocesso, mesmo que não houvesse tantas garantias, pois foi constatada uma derrocadae um aceleramento no processo de extermínio. Por influência da Revolução Francesa (1789) e seu ideal de sociedade desenvolvida, a questão indígena passou a ser considerada um problema. Havia discussão se o povo indígena devia ser exterminado ou preservado. Acerca desse contexto Paraiso (2010, p. 13), esclarece:

\footnotetext{
Na visão dos constituintes, essa condição devia-se ao fato de os índios não gozarem dos cômodos e incômodos de pertencerem à sociedade brasileira, uma vez que não participavam do Pacto Social que constituíra o Estado e por não estarem submetidos ou reconhecem o Império ou sua autoridade já que viviam em guerra com os brasileiros.
}

O período imperial demonstra que ao invés de uma melhora em relação aos direitos dos indígenas, ocorreu o oposto. Esse passou a ser visto como algo a parte do Brasil, como se se fosse um entrave ao progresso. Ou seja, não obstante com a colonização que extinguiu inúmeros povos indígenas, nesse período, o Brasil continuou perpetuando fatores que gerassem a vulnerabilidade.

\subsection{REPÚBLICA VELHA}

O período republicano deu início em 1889 e, por parte das elites, havia um projeto de modernização do Estado brasileiro. O novo governo lançou no ano de 1889 um decreto que delegava responsabilidade aos Estados em relação aos indígenas, além disso, criou o Ministério dos Negócios da Agricultura, Indústria e Comércio que tinha, entre várias funções descritas no próprio nome, auxiliar questões relacionadas aos indígenas. Somente em 1910 foi criado, por Nilo Peçanha, o Serviço de Proteção aos índios e Localização dos Trabalhadores Nacionais que passou a tratar de assuntos relacionados aos indígenas.

A proposta do Serviço de Proteção aos índios e Localização dos Trabalhadores Nacionais (SPILTN) era inserir o indígena na lógica capitalista, transformando-os em mão de obra barata a ser explorada, porém, essa exploração era menos explícita. Esse processo não respeitava a alteridade étnica (PRESTES et al., 2017).

Campo Jurídico|Barreiras (BA) | v.9 |e676| p.01-34 |Janeiro-Junho|2021 
Já em 1918, o nome SPILTN é alterado para Serviço de Proteção ao Índio (SPI), inicialmente vinculado ao Ministério da Agricultura, Industria e Comércio (PRESTES et al., 2017 apud ALMEIDA, 2015).

\subsection{ERA VARGAS (1930-1945)}

Com lastro nos ensinamentos de Garfield (2000, p. 14), “em agosto de 1940, o presidente Getúlio Vargas visitou a aldeia dos índios Karajá na Ilha do Bananal, no Brasil Central. Foi o primeiro presidente brasileiro a visitar uma área indígena, ou o Oeste da nação nesse sentido".

O Estado Novo tinha um projeto de desenvolvimento e integração do Brasil. Um símbolo do período ditatorial de Getúlio Vargas, em relação aos indígenas, foi sua visita a aldeia dos índios Karajá e o projeto intitulado anteriormente como "Marcha para o Oeste" com o objetivo de desenvolvimento dessas regiões em sentido populacional e econômico, justificada por Garfield (2000, p. 16):

Mais de $90 \%$ da população brasileira ocupava cerca de um terço do território nacional. $\mathrm{O}$ vasto interior, principalmente as regiões Norte e Centro-oeste, permanecia esparsamente povoado. Muito índios, é claro, fugiram para o interior justamente por estas razões. Mas os seus dias de isolamento, anunciou o governo, estavam contados.

Lembrando que o Serviço de Proteção aos Índios ainda era responsável pela proteção do povo indígena. Porém, sua função passou a ser doutrinária em relação aos indígenas. Como bem tangenciado pelo autor, “o Estado extirparia as raízes do nomadismo, convertendo índios e sertanejos em cidadãos produtivos. O SPI iria doutrinar os índios, 'fazendo-os compreender a necessidade do trabalho'." (GARFIELD, 2000, p. 15).

Por fim, seguindo a ideia de Garfield "os índios certamente deveriam ser integrados à sociedade brasileira; como declarou o SPI: 'Não queremos que o índio permaneça índio. Nosso trabalho tem por destino sua incorporação à nacionalidade brasileira, tão íntima e completa quanto possível'." (GARFIELD, 2000, p. 18). 


\subsection{GOVERNOS MILITARES}

O golpe ocorrido em 1964 por um grupo de militares, apoiados por camadas da população civil derrubou um presidente eleito democraticamente. Em 1964 não se sabia ao certo qual era o número de índios que viviam no país, pois havia apenas estimativas. Mas, aqueles que residiam no país foram alcançados ao longo de séculos por atividades predatórias, como garimpos e desmatamentos, ou pelos projetos oficiais de desenvolvimento econômico e de ocupação do solo (VALENTE, 2017).

No Período da Ditadura Civil-Militar, estima-se que mais de 8 mil índios foram mortos. Ou seja, esse é mais um capítulo na história que demonstra o processo de genocídio em relação aos povos originários.

No período da ditadura, havia parcerias entre empresas e a Funai, e conforme Brasil e Farias (2014, p. 1), "Em setembro de 1982, após um convênio ilegalmente firmado entre a Funai e a Petrobras, a mesma empresa voltou a invadir o território Sateré-Mawé, segundo o relatório".

Delineava-se um quadro de sistemática colaboração entre funcionários e agentes privados (fazendeiros, seringalistas, madeireiras e mineradoras, entre outros) no saqueio dos territórios indígenas e na exploração da força de trabalho nativa (ALARCON, 2018).

\subsection{AFINAL, O QUE EXPLICA A VULNERABILIDADE DO INDÍGENA?}

Os fatos supracitados são importantes para validar o argumento de genocíd io dos povos indígenas, demonstrando que para realizar o recorte temporal acerca da situação excepcional da pandemia causada pelo novo Coronavírus, é necessário demonstrar que o descaso por parte do Estado para com esse grupo demonstra como o processo de vulnerabilidade é enraizado e, essa situação atípica epidemiológica, está funcionando como um catalisador no sentido de desaparecimento de vidas indígenas. Da colonização à República, década após década, a violência contra esse povo não se extingue (DHILLON, 2018). A ineficácia do Estado em garantir direitos para essas pessoas não ocorre no plano da eficácia, e passamos a entender que o que caracteriza a vulnerabilidade é a violência contra a minoria. Nesse sentido citamos Rogers e Ballantyne (2008, p. 32), que expõem sua dúplice visão acerca da vulnerabilidade, ao qual se divide em:

\section{Campo Jurídico|Barreiras (BA) | v.9 |e676| p.01-34 |Janeiro-Junho|2021}


a) vulnerabilidade extrínseca - ocasionada por circunstâncias externas, como falta de poder socioeconômico, pobreza, falta de escolaridade ou carência de recursos; e b) vulnerabilidade intrínseca - causada por características que têm a ver com os próprios indivíduos, tais como doença mental, deficiência intelectual, doença grave, ou os extremos de idade (crianças e idosos).

A vulnerabilidade extrínseca fica evidente com a situação do povo indígena dentro da sociedade brasileira. Ora não sendo detentores de direitos, ora sendo reconhecida a responsabilidade do Estado para sua preservação e, até mesmo, sendo alvo de debates da sua proteção ou extinção. Mas algo que não muda, na prática, são as violações contínuas, de maneira explícita e velada, como explicado no período do Estado Novo, por exemplo. Os costumes dos povos não eram respeitados, havia tentativas de aculturação e escravização, muitas vezes, com apoio da SPI que tinha a função de proteger os interesses dos índios.

Já em relação à vulnerabilidade intrínseca, é possível entendê-la como um desd obramento de tod o o processo histórico que paira entorno da figura indígena. Compreender que são diferentes dos cidadãos brasileiros, não dignos de proteção e respeito por conta de sua cultura, se enquadra dentro da dimensão intrínseca da vulnerabilidade. Concernente com isso, Sodré $(2005$, p. 4) relaciona o conceito de grupos minoritários com grupos vulneráveis, além de caracterizar pontos de convergência entre os grupos:

Vulnerabilidade jurídico-social - por ser um grupo institucionalizado pelas regras do ordenamento jurídico-social vigente, logo, muitas vezes não acampado pelas políticas públicas, a razão paralutar por voz e reconhecimento societário de seu discurso.

Nesse ponto, cabe ressaltar como o grupo indígena se enquadra, também, dentro da vulnerabilidade jurídico-social, quando não há efetividade em lhes garantir o mínimo sem que haja alguma espécie de aculturação. Além disso, o Estado se mostra indiferente com a questão de violação dos direitos desse grupo minoritário, isso é claro quanto a falta de políticas públicas - efetivas -, que visem a proteção desse grupo minoritário.

Em adição, Carmo (2016, p. 11) nos ensina a importância de se pensar numa sociedade que tenha como princípio a alteridade:

Dessa maneira, percebemos uma construção intersubjetiva tensiva e conflituosa de um eu que só se configura como tal na alteridade, isto é, em sua relação com o outro, num contexto em que muitas variáveis estão envolvidas. E, nessa mesma esteira, diferenças no modo de agir, pensar e sentir também 
são suportadas, ou seja, toleradas, porque nunca foram verdadeiramente colocadas como alternativas legítimas numa sociedade plural e que se quer democrática.

A construção de uma sociedade verdadeiramente plural se debruçaria em políticas públicas, porém, o que há dentro do território brasileiro é o descaso histórico (MARÉS DE SOUZA FILHO, 1998). Cita-se que, em tempos de pandemia, ao mesmo tempo que a vulnerabilidade se intensificou, a demanda por justiça social ganhou força quando encontrou eco na seguridade social. Ou seja, a deficiência estatal em amparar e assistir os indígenas decorre de um processo histórico que, ao mesmo tempo que o Estado cria algumas políticas públicas destinadas a eles (e em alguns governos nenhuma), vemos um desinteresse explícito em garantir a existência desse grupo minoritário. Isso foi ressaltado ainda mais durante a pandemia, onde houve uma nítida falta de efetividade em garantir a prevenção da proliferação do vírus nas áreas indígenas. Portanto, é conveniente analisar que a falta de ações para conter o vírus nas tribos indígenas pode ser considerada uma ferramenta de um processo de genocídio, em curso, desse grupo.

Nesse viés, verifica-se a viabilidade de levantar essa discussão acerca do possível genocídio indígena. Arrimo-me, para tanto, no ensinamento de Will (2014, p. 127), ao aduzir que "os diversos grupos indígenas podem sucumbir, se já não sucumbiram, a um genocídio silencioso, em pleno século XXI, resultado quer da impunidade do Estado brasileiro quer da impotência da comunidade internacional em preveni-lo ou erradicá-lo".

Seguindo o raciocínio, Will (2014, p. 128) aind a preleciona que:

Ora, os grupos étnicos indígenas aindaestãolonge de viverem numa sociedade livre de tal flagelo, forjado sob a influência de um contexto onde permanecem controvertidos muitos pontos na dogmática do crime de genocídio, e onde seus direitos foram fragilmente incrustados no Direito Internacional e no Nacional. E se direcionarmos nossa atenção para a política estatal no que diz respeito às questões que lhes concernem, igualmente, concluiremos que esses são um dos motivos pelos quais ainda não avançamos muito no combate desse horrendo crime.

Em suma, o processo que gerou a vulnerabilidade de grupos indígenas perdura desde 1500. Há uma sistematização que comprova um genocídio em curso, dado o fato de que, em cada período da história, a figura do indígena foi ressignificada - para bem ou para mal. Quando seus direitos foram minimamente reconhecidos pelo ordenamento jurídico, a efetivação não 
ocorreu no plano da eficácia e essa história de abandono e descaso tem o agravante, em 2020, por conta da situação de pandemia global e os grupos vulneráveis são os que mais sofrem.

\section{DIMENSÕES DA DISCRIMINAÇÃO INDÍGENA}

É possível identificar através da construção histórica o enquadramento do grupo indígena em diferentes dimensões da discriminação, porém cabe ressaltar que o presente artigo utiliza o termo "grupo indígena" apenas para fins metodológicos, pois, dentro do grupo indígena há diferentes especificidades que devem ser respeitadas à luz da alteridade. Portanto, para a discriminação funcionar é necessário algo que lhes confira poder, ou seja, sem essa prerrogativa é impossível atribuir vantagens ou desvantagens aos grupos (ALMEIDA, 2019). Em suma, um agente discrimina uma pessoa em relação a outra quando ele lhe impõe uma desvantagem por pensar que ela não tem uma determinada característica que outras pessoas possuem, mas é necessário que a parte que discrimina ativamente esteja empossada de poder (MOREIRA, 2019).

Neste ponto, cabe apontar que não é apenas por acreditar que membros do grupo majoritário possuem características socialmente valorizadas, que a discriminação ocorre. Mas, também, a discriminação acontece para manter os privilégios do grupo dominante em detrimento de grupos minoritários (RODRÍGUEZ, 2016). Para além dessa compreensão discriminatória, a qual prega veementemente que o grupo dos indígenas não são atores sociais competentes, cabe lembrar que a legislação brasileira busca, amplamente, garantir a proteção e os direitos desse grupo, porém tais aspectos não são observados na prática.

A discriminação, em síntese, ocorre de forma corriqueira no Estado brasileiro (MOREIRA, 2020). Mas, é importante salientar que discriminar de maneira positiva é um método para se alcançar uma equidade dentro de um Estado Democrático de Direito (RIOS, 2008). A par disso, ressalta-se que o objetivo do Estado de Direito é a proteção do indivíduo em face do poder político do Estado, colocando-o no centro do ordenamento jurídico e assegurando seus direitos fund amentais (CARDIN; CRUZ, 2020; CANOTILHO, 1941). Nessa perspectiva, a dignidade da pessoa humana pode ser retratada de duas maneiras: a primeira como uma qualidade significativa do ser humano, englobando a sua essência; e a segunda como um motivo de manter a ordem política e a paz social (SZANIAWISKI, 2005).

\section{Campo Jurídico|Barreiras (BA) | v.9 |e676| p.01-34 |Janeiro-Junho|2021}


Posto isso, busca-se discriminar, positivamente, quando esta discriminação possui um caráter legítimo por parte doEstadoe seja para se alcançar um bem para o grupo historicamente vulnerável (PIOVESAN, 2005). Com efeito, é possível observar no artigo 231 da Constituição Federal de 1988, uma discriminação positiva: "São reconhecidos aos índios sua organização social, costumes, línguas, crenças e tradições, e os direitos originários sobre as terras que tradicionalmente ocupam, competind o à União demarcá-las, proteger e fazer respeitar todos os seus bens" (BRASIL, 1988).

Já a discriminação negativa é o oposto, ela não é orientada para a equidade, ela tem por objetivo manter as classes minoritárias como estão ou, até mesmo, piorar a situação desse grupo, algo que vai contra o Estado Democrático de Direito. Sobre ambas as dimensões citadas, Moreira e Calfat Neto (2016, p. 23) bem lecionam: “A discriminação positiva pode ser distinguida da discriminação negativa porque que ela cria uma vantagem temporária ou permanente para membros de um determinado grupo que possui uma história de desvantagem ou que estão em uma situação de vulnerabilidade".

Acerca das dimensões discriminatórias, há os modos diretos ou indiretos. No caso de discriminação direta, ocorre o repúdio ostensivo à indivíduos ou grupos, motivado pela condição racial. No caso da discriminação direta, conforme bem apontam Moreira e Calfat Neto (2016, p. 10): “O conceito de discriminação direta pressupõe que as pessoas são discriminadas a partir de um único vetor e também que a imposição de um tratamento desvantajoso requer a existência da intenção de discriminar". Por fim, é importante observar que o conceito de discriminação direta é altamente perigoso, pois, pode deixar subentendido que atores sociais sempre agem de maneira racional e a discriminação direta seria apenas um desvio de tal racionalidade. Por derrad eiro, esse método de discriminação seria apenas um desvio do padrão e esse pressuposto pode deixar velado a dimensão estrutural da discriminação (MOREIRA; CALFAT NETO, 2016).

Dando sequência a esta linha de pensamento, a dimensão estrutural pode ser compreendida desde o processo de colonização do Brasil, o qual deu início ao genocídio indígena até o momento da pandemia de Coronavírus, a qual acentuou os riscos para esse povo. É preciso frisar que, principalmente, por ser uma dimensão a qual engloba práticas arbitrárias e desvantagens sociais já enraizadas, a estrutura acaba corroborando para a permanência desse grupo em uma situação de desvantagem, como por exemplo, a exposição aos riscos da Covid19 em relação à população indígena no Brasil. 
Interessa anotar, nesse passo, que a discriminação indireta abrange práticas discriminatórias que atingem um ou mais grupos minoritários de maneira menos explícita. Nessa dimensão, é importante apontar que não há uma atenção direcionada àquele grupo em questão, mas na ausência de se observar as especificidades de um determinado grupo, acaba ocorrendo uma exclusão, uma marginalização e, de fato, uma discriminação (RODRÍGUEZ, 2016). Com base no exposto, é importante resgatar um dos ensinamentos de Moreira e Calfat Neto (2016, p. 23) que elucidam a dimensão indireta:

Ao contrário do que se pensa, a discriminação pode ocorrer mesmo na ausência objetiva da intenção de discriminar um indivíduo e também mesmo em situações nas quais não há a utilização de formas de diferenciação legalmente vedadas. Uma norma jurídica ou uma política pública pode obedecer ao princípio da generalidade, não sendo então dirigida a nenhum grupo específico. Porém, a sua aplicação pode ter um ef eito desproporcional sobre uma determinada classe de indivíduos, o que caracteriza a discriminação indireta.

Com base nas duas dimensões examinadas, podemos relacionar a experiência de diferentes povos indígenas na pandemia da Covid-19 com as discriminações sofridas no Brasil.

Segundo o Conselho Indigenista Missionário (Cimi), o número de suicídios entre os indígenas em 2017 foram de 128, superando o número de assassinatos, que foram 118. Sérgio Martins da Silva, da Aldeia Aguapeu, afirma que a discriminação é um ponto que reflete no aumento dos suicídios indígenas: "Se a gente procurar, mesmo capacitados, com formação em alguma coisa, sempre seremos os últimos dos últimos a serem escolhidos. Por isso que a integração nunca vai dar certo" (GOIS; BRUNO, 2019, p. 3). Nesse exemplo, fica clara uma discriminação organizacional, porém, não se esgota apenas nessa dimensão. Temos a discriminação em seu aspecto direto e, por fim, estrutural, pois, esta não depende de um indivíduo para ocorrer, porém, envolve regras culturais e práticas institucionais que mantêm grupos em um estado de desvantagem.

O caráter indireto da discriminação pode ser observado com base em um levantamento do Instituto de Estudos Socioeconômicos (Inesc) requisitado pela BBC News Brasil, ao qual indica que, mesmo com a crise do coronavírus, o total gasto pelo governo na saúde indígena no primeiro semestre deste ano ficou abaixo da despesa registrada na primeira metade de 2019 (SCHREIBER, 2020). 
Conclui-se, nesse ínterim, mencionand o a teoria da discriminação interseccional, a qual afirma que a luta contra a opressão social requer a consideração das múltiplas formas de discriminação sofrida por indivíduos que pertencem a diferentes grupos minoritários, assim, compreendendo que dentro do grupo indígena há outro grupo: mulheres indígenas, pessoas portadoras de deficiência, crianças, etc. Em alusão ao tema, Moreira (2016, p. 1571) aduz:

Assim, a noção de discriminação interseccional designa as formas como vetores específicos de discriminação confluem para formar uma vivência social particular construída a partir das formas como racismo e sexismo restringem simultaneamente as oportunidades de um grupo social.

De tudo que foi apresentado, infere-se, por fim, que para compreender as dimensões de discriminação é importante entender as especificidades dos diferentes grupos indígenas e atentar-se ao fato de que não se trata de um grupo homogêneo, mas sim heterogêneo.

\section{A REPRESENTATIVIDADE INDÍGENA NA POLÍTICA}

O termo referente à democracia diz respeito ao poder que emana do povo, trazendo consigo uma ideia de socied ade igualitária e liberta para expressar sua opinião diante o governo, procurando promover o melhor para o conjunto social como um todo (CANOTILHO, 1941; CARVALHO, 2004; SARLET; MARINONI; MITIDIERO, 2020; SILVA, 2021).

Mário Juruna, parlamentar, realizou um discurso no plenário da câmara federal em homenagem ao Dia do Índio, onde disse: "Eu quero que gente trate índio brasileiro o mais possível dentro do melhor. Cada um de nós tem consciência e cada um de nós tem capacidade. Ninguém tem menos capacidade" (STREIT, 2018, p. 1). Isso apenas demonstra como a política indígena ainda é extremamente defasada no Brasil, pois, além de quase não possuir uma participação dos povos indígenas, também são questionadas as suas capacidades dentro de um âmbito político.

Como dito anteriormente, a democracia possui como essência sua representatividade, viabilizando que o povo possua o direito de exigir seus direitos perante o Estado. Contudo, os grupos minoritários se encontram desprezados pelos grupos majoritários.

Isso foi feito com os índios durante a história, pois desde sempre os governantes reduziram os povos indígenas a um único termo "índio" ao invés de nomear cada tribo ou nações indígenas, além de tentarem normatizar uma única linguagem padrão com o fim de

Campo Jurídico|Barreiras (BA) | v.9 |e676| p.01-34 |Janeiro-Junho|2021 
entendimento na comunicação (MARÉS DE SOUZA FILHO, 1998). Isso reforça uma visão eurocêntrica que o mundo ainda possui, onde buscam unificar culturas, línguas e o direito, acabando por silenciar a diversidade (DORNELLES, 2018).

Com isso, é notória a necessidade da abrangência de um multiculturalismo, para que assim os direitos fundamentais indígenas possam ser reforçados e mais amplamente representados pelos próprios indígenas (MCLAREN; 1997; OLIVÉ, 1999; LOPES, 2008).

\section{O ISOLAMENTO COMO DEFESA: A EXPOSIÇÃO INDÍGENA AO RISCO DE CONTAMINAÇÃO PELA COVID-19}

A questão da exposição dos indígenas ao novo Coronavírus deve ser entendida, primeiramente, como uma falha no dever de cuidar desse grupo vulnerável (MANTELLI; ALMEIDA, 2019). Por se tratar de um grupo minoritário que opta pelo isolamento, algo que é bom para a prevenção de contaminação do vírus, esse grupo dificilmente teria meios para garantir a saúde caso houvesse a epidemia chegasse na aldeia, ou seja, as consequências seriam devastadoras, indo de encontro à extinção de uma aldeia inteira (ROCHA; PORTO; PACHECO, 2019).

Segundo consta nas diretrizes daFunai, são considerados “isolados” os grupos indígenas que não estabeleceram contato permanente com a população nacional, diferenciando-se dos povos indígenas que mantêm contato antigo e intenso com os não-índios (FUNAI, 2020).

No âmbito nacional, o Brasil na Constituição Federal de 1988, em seu art. 231, reconhece a organização social e as tradições dos indígenas, além disso, deixa claro dentro do texto o dever de proteger esse grupo, garantindo-lhes o direito de manter sua cultura como um todo, sendo, portanto, dever do Estado tutelar essa proteção contra qualquer violação de direitos.

Não há como classificar os povos indígenas como um grupo homogêneo, o correto é entender que há diferentes povos com diferentes culturas (BARRETO, 2003). Isso se evidência quando constatamos que há povos que são amistosos com contatos de fora da tribo, há regiões que há integração e modificação cultural com o passar do tempo, como por exemplo, a pesquisa de Castro (2018, p. 3) demonstra:

A maneira como cada povo se insere na sociedade brasileira é bastante variada. Há povos cujos membros trabalham no mercado regional e são Campo Jurídico|Barreiras (BA) | v.9 |e676| p.01-34 |Janeiro-Junho|2021 
assalariados, como os Guarani Kaiowá, envolvidos em atividades de corte de cana-de-açúcar para as destilarias de álcool do estado do Mato Grosso do Sul. Há aqueles que vivem em centros urbanos, como as famílias de SateréMawé na periferia de Manaus e os Pankararu, migrantes do estado de Pernambuco e que hoje habitam a favela Real Parque na cidade de São Paulo.

Há também grupos que tendem ao isolamento, seja por motivos culturais, seja por proteção. A Fund ação Nacional do Índio (FUNAI) elucida que há diversos motivos que explica o isolamento dos indígenas, entre eles, é possível que os povos indígenas que vivem isoladamente ou têm pouco contato fora da tribo, tenham optado por se afastar o máximo possível por conta de encontros que tiveram resultados negativos para a sobrevivência da tribo, em relação a isso, podemos elencar: Infecções, doenças, epidemias e morte, atos de violência física, espoliação de seus recursos naturais ou eventos que tornam vulneráveis seus territórios, ameaçando suas vidas, seus direitos e sua continuidade histórica como um grupo (FUNAI, 2020).

Com a decretação da pandemia, esperava-se que nenhuma pessoa de fora das tribos entrasse em contato com elas, pois uma vez que um vetor transmitisse o vírus à população indígena a catástrofe seria grande, pois o sistema imunológico dos indígenas é mais vulnerável e suscetível a contrair o vírus. Portanto, alinhado ao fato de que esse grupo tem um difícil acesso à saúde pública por viverem isolados dos centros urbanos, uma doença que é facilmente transmissível poderia facilmente se alastrar nas tribos, ainda por cima por estarem constantemente aglomerados praticando suas tradições culturais.

Houve muitas pessoas alheias às tribos, como missionários evangélicos, que adentraram algumas tribos durante a pandemia sem autorização da FUNAI. Os indígenas, após esses contatos não planejados e autorizados, temeram que essas pessoas pudessem estar contagiadas com vírus que poderia rapidamente se alastrar pelos moradores da tribo (ROSHA, 2020).

Há de se destacar que o Supremo Tribunal Federal, por meio da ADPF 709, referendou medidas de enfrentamento da Covid-19 em terras indígenas. Dentre as medidas acatadas, ressalta-se a criação de barreiras sanitárias, a acessibilidade desse povo ao Subsistema de Saúde Indígena e a elaboração de um plano de combate ao vírus em parceria com a União, o Conselho Nacional de Direitos Humanos e as comunidades indígenas propriamente ditas. Essa arguição, que teve como relator o Ministro Roberto Barroso, partiu do pressuposto que houve omissão do Poder Público em combater a doença causada pelo coronavírus nas tribos indígenas (BRASIL, 2020). Uma das premissas da decisão é diretamente ligada à vulnerabilidade desse 
grupo social quanto a baixa imunidade à doenças contagiosas, ressaltand o a necessidade de isolamento:

\begin{abstract}
No que respeita aos povos indígenas em isolamento ou de contato recente, a opção pelo não contato decorre de seu direito à autodeterminação e constitui uma forma de preservar a sua identidade cultural e as suas próprias organizações, usos, costumes e tradições. Nessa medida, o ingresso de qualquer membro exógeno à comunidade, sem a sua autorização, constitui um ilícito. Tais povos têm direito ao isolamento e o Estado tem o dever de assegurá-lo. (BRASIL, 2020, p. 11).
\end{abstract}

Por fim, ressalta-se que o fato de as tribos indígenas viverem de forma isolada seria uma ótima premissa para que nenhum deles fossem contaminados por pessoas de fora. Entretanto, interesses alheios e despreocupados acabaram por se sobrepor à prevenção do contágio. Por conseguinte, esses diversos indígenas infectados em diferentes tribos enfrentaram grandes dificuldades de obter assistência médica pois o acesso à saúde para os indígenas enfrenta muitas complicações, tanto no âmbito geográfico quanto no âmbito social (CARDOSO, 2014).

\title{
5 MECANISMOS LEgAiS: A RESSIGNIFICAÇÃO DO PAPEL DO ESTADO ACERCA DAS QUESTÕES INDÍGENAS
}

Um marco histórico dentro da nova república foi a promulgação da Constituição Federal de 1988 que teve um forte apelo às garantias fundamentais de modo geral e, além disso, no art. 231 buscou garantir certas direitos aos povos indígenas, colocando a responsabilidade no Estado em tornar efetiva essa proteção, como é descrito: "São reconhecidos aos índios sua organização social, costumes, línguas, crenças e tradições, e os direitos originários sobre as terras que tradicionalmente ocupam, competindo à União demarcá-las, proteger e fazer respeitar todos os seus bens" (BRASIL, 1988).

De forma a prosseguir com recortes de períodos históricos (como visto no tópico dois do presente trabalho), nesse ponto seremos inclinados a observar a questão indígena sob a luz dodireito, demonstrando mecanismos legais que buscam efetivar direitos à essa minoria. Nesse sentido, como bem expõe Silva (2018, p.15), “Tratar do 'direito à terra' e da necessidade da demarcação das terras indígenas frente às ameaças da apropriação capitalista do campo é tratar do desenvolvimento concreto da singularidade indígena e sua interlocução com o complexo social total: como um ser social".

Campo Jurídico|Barreiras (BA) | v.9 |e676| p.01-34 |Janeiro-Junho|2021 
Por esse turno, dentro da Constituição de 88, é assegurado direito à educação para indígenas, criando mecanismos legais para conferir-lhes direitos como qualquer outro cidadão brasileiro, mas, nesse caso observando o pluralismo que há nesse grupo, assim elucida o artigo publicado pela revista Povos Indígenas no Brasil:

Note-se que o direito à diferença não implica menos direito nem privilégios. Daí porque a Carta de 88 tenha assegurado aos povos indígenas a utilização das suas línguas e processos próprios de aprendizagem no ensino básico (artigo $210, \S 2^{\circ}$ ), inaugurando, assim, um novo tempo para as ações relativas à educação escolar indígena. (POVOS INDÍGENAS NO BRASIL, 2018)

Além disso, a Constituição Federal reconhece essas terras ocupadas pelos povos indígenas como bens da União, aos moldes do art. 20, XI e, com isso, preceitua que é dever do Estado a preservação, além disso, como aludido, reconhecendo que essas terras ocupadas por indígenas encontram substrato na legalidade.

Porém, apesar de encontrarem resguardo dentro da Constituição Federal de 1988, ainda acabam por serem alvos de ataques ilegais, pois, supostamente sua ocupação de terras demarcadas entra em conflito com interesses econômicos, como bem explica Silva (2018, p. 17):

\begin{abstract}
As leis contemporâneas voltadas à proteção das demandas e necessidades próprias dos povos indígenas são resultado de muita luta, organização dos próprios indígenas e articulação com os órgãos que atuam em sua defesa. Também estão constantemente ameaçados porque entram em confronto com os processos materiais, com a realidade econômica dos empreendimentos capitalistas de exploração dos recursos naturais que ainda estão nas mãos dos povos originários.
\end{abstract}

Nesse sentido, é possível relacionar que a demarcação de terras em favor dos povos indígenas, através de muita luta, tem um caráter simbólico, pois, o objetivo é demonstrar o quão estão preocupados com a extensão da posse e asseguração plena dos dispositivos constitucionais (SANTOS FILHO, 2005).

No que se refere às chamada Terras Indígenas, a Constituição estabelece: São bens da União, conforme art. 20 XI; são destinadas à posse de grupos indígenas (art. 231, § 2); são nulos e extintos os atos jurídicos que afetam essa posse, a não ser que seja relevante para o interesse público da União (art. 231, §6); somente os povos que ali vivem podem desfrutar das riquezas do solo, rios e dos lagos ali existentes (art. 231, §2); o aproveitamento de recursos hídricos, a 
pesquisa e a lavra das riquezas minerais, só poderá ocorrer com autorização do Congresso Nacional, além de ser necessário ouvir as comunidades que serão afetadas (art. 176, §1); as terras são inalienáveis e indisponíveis (art. 231, §4); é vedado a tentativa de remover os índios de suas terras, a não ser que seja em casos excepcionais e/ou temporários (art., 231, §5).

Por fim, vale citar o Estatuto do índio (Lei 6.001) de 1973, ao qual trata das relações do Estado e da sociedade brasileira com os povos indígenas. Foi estabelecido com o princípio do Código Civil de 1916, de que os índios eram relativamente incapazes e deveriam ser tutelados por um órgão indigenista estatal, pensamento esse que foi superado pela Constituição de 88, porém, é importante citar para fins demonstrativos da ressignificação da figura do índio.

Dentre os 68 artigos que há dentro do Estatuto do Índio, vale a pena ressaltar para esta pesquisa os seguintes:

Art. $2^{\circ}$ Cumpre à União, aos Estados e aos Municípios, bem como aos órgãos das respectivas administrações indiretas, nos limites de sua competência, para a proteção das comunidades indígenas e a preservação dos seus direitos:

$[\ldots]$

II - prestar assistência aos índios e às comunidades indígenas ainda não integrados à comunhão nacional;

III - respeitar, ao proporcionar aos índios meios para o seu desenvolvimento, as peculiaridades inerentes à sua condição;

IV - assegurar aos índios a possibilidade de livre escolha dos seus meios de vida e subsistência;

V - garantir aos índios a permanência voluntária no seu habitat, proporcionando-lhes ali recursos para seu desenvolvimento e progresso. (BRASIL, 1973).

Em relação ao art. $2^{\circ}$, fica clara a aparente preocupação do Estado em garantir, ao menos no plano das normas, mecanismos legais de proteção do desse grupo minoritário. A ideia de alterid ade não estava presente, mas havia uma concepção de assimilação, ou seja, observavamse esperanças que o indígena se integrasse aos poucos, como veremos a seguir no art. $9^{\circ}$ :

Art. $9^{\circ}$ Qualquer índio poderá requerer ao Juiz competente a sua liberação do regime tutelar previsto nesta Lei, investindo-se na plenitude da capacidade civil, desde que preencha os requisitos seguintes:

I - idade mínima de 21 anos;

II - conhecimento da língua portuguesa;

III - habilitação para o exercício de atividade útil, na comunhão nacional; IV - razoável compreensão dos usos e costumes da comunhão nacional. (BRASIL, 1973). 
A figura do indígena, quanto ao entendimento de individuo no âmbito jurídico, era de uma pessoa relativamente incapaz. Aqui, verifica-se que o Estad o não teve preocupação alguma em entender as especificidades desse povo. A preocupação maior do Estado deveria ser a da efetivação, ou seja, tornar os direitos adquiridos mais eficazes no plano concreto, mesmo que sejam asseguradas garantias constitucionais. Ainda complementa-se que haja órgãos governamentais e não-governamentais interessados em preservar esse grupo vulnerável, já que por conta de interesses econômicos, eles são vítimas de violações (VERSOLATO; GOMES, 2016).

\section{A SITUAÇÃ O INDÍGENA À LUZ DA TEORIA DE NANCY FRASER}

Sobreleva, em arremate, fazer menção à teoria de Nancy Fraser, importante filósofa e professora estadunidense da New School University, em Nova Iorque. Tal intelectual visa analisar principalmente a questão de justiça, que deve ser interpretada através de três óticas: distribuição, reconhecimento e representação. Para tanto, Fraser formula a teoria da justiça bivalente, ao qual o pressuposto fundamental e central dessa teoria é a ideia de paridade de participação. Essa ideia remete, sumariamente, que todas as pessoas devem participar como pares na sociedade.

Essa concepção bidimensional de justiça propõe que uma sociedade justa é aquela na qual todas as pessoas são vistas e tratadas como atores sociais competentes. Destarte, para que possamos atingir esse objetivo em relação às pessoas, faz-se necessário promover as condições objetivas e subjetivas de paridade de participação (FRASER, 2008; MOREIRA, 2020).

As condições objetivas de paridade de participação pressupõem que as pessoas de uma sociedade, para que possam operar de maneira adequada nos espaços públicos, devem ter um nível máximo de seguridade social que só pode ser alcançado através de direitos sociais e políticas redistributivas, por exemplo. Em adição, segundo Fraser, os seres humanos só podem ser livres e tomar decisões autônomas quando eles tem o mínimo de segurança social (FRASER, 2008).

As condições subjetivas de paridade de participação, por sua vez, exprimem que é necessário realizar uma mudança na cultura das instituições com o propósito de combater o preconceito, dado o fato de que as características que as geram (raça, sexo, compleição física, etc.) são traços benignos. Ou seja, entende-se que as qualidades dos sujeitos, que geram

Campo Jurídico|Barreiras (BA)| v.9 |e676| p.01-34 |Janeiro-Junho|2021 
discriminações, se encontram fora do controle das pessoas e são irrelevantes para o exercício dos direitos ou para a atuação competente dos indivíduos na esfera pública. Uma vez que ao combatermos as diferentes formas de preconceitos, nós ao mesmo tempo promovemos uma sociedade baseada no reconhecimento, que é um dos pilares fundamentais da teoria de Fraser (FRASER, 2008).

Precisa a lição de Bavaresco e Lima (2015, p. 150) a propósito do tema, quando afirmam que:

A paridade de participação enquanto um princípio deontológico de universalização de direitos pressupõe o igual acesso a bens básicos (modelo redistributivo), o igual respeito (modelo do reconhecimento) e a igual deliberação concernente à esfera pública (participação política).

É precípuo contemplar, ainda, que quando pensamos na justiça sob o prisma da perspectiva bivalente de Fraser quanto a paridade de participação, depreende-se a conexão entre a redistribuição e o reconhecimento, que são dois conceitos que englobam o coração de sua proposta.

Dentro dessa perspectiva, Fraser (2008, p. 157) nos ensina que "no mundo de hoje, as demandas por justiça social parecem, cada vez mais, dividir-se em dois tipos", sendo elas as demandas, como outrora aduzidos, redistributivas e de reconhecimento.

No contexto indígena, parece-nos mais oportuno analisarmos sobre égide da política de reconhecimento, uma vez que tal grupo social encontra-se ligeiramente desamparado pelo Estado, e ainda mais evidente no cenário de crise sanitária. A propósito, na lição de Pontes et al. (2020, p. 1), poder-se-á dizer que:

Os povos indígenas, ao longo da história, têm sidoparticularmente impactados por epidemias de doenças infecciosas, muitas das quais inclusive contribuíram para o apossamento de territórios e outros recursos. Estendendo-se a todos os âmbitos da vida dessas coletividades, seusefeitos sãoprofundos e duradouros. A epidemia de COVID-19 traz o risco de um novo genocídio, em um cenário já caracterizado por violações sistemáticas de direitos e intensa violência contra os indígenas.

O objetivo da política de reconhecimento, segundo Fraser (2008, p. 167), “é contribuir para um mundo amigo da diferença, onde a assimilação à maioria ou às normas culturais dominantes não é mais o preço do igual respeito". Assim, a teoria do reconhecimento de Fraser 
foca nas injustiças culturais "as quais presume estarem enraizadas nos padrões sociais de representação, interpretação e comunicação. Os exemplos incluem dominação cultural, nãoreconhecimento e desrespeito" (FRASER, 2008, p. 170).

No cerne dos indígenas, a teoria de Nancy Fraser compreende-se como uma forma de luta para que os indígenas sejam reconhecidos como atores sociais competentes, ou seja, como indivíduos capazes de atuar nos espaços públicos. O olhar pormenorizado à comunidade indígena resulta numa falta de representatividade política e social dessa comunidade. Perfilho o entendimento de Paula (2017, p. 314), ao inferir que:

Se para esses segmentos socioculturais a busca pela afirmação de direitos é constante nos mais variados contextos ampliados de inserção indígena, as respostas concretas e positivas são lentas, fragmentadas e tendencialmente esquizofrênicas por parte do Estado em suas esferas municipal, estadual e federal.

Notória é a importância da teoria de Fraser (2008, p. 170) para encontrar uma forma de superar a injustiça:

O remédio para a injustiça é a transformação cultural ou simbólica. Isto envolveria, sobretudo, a reavaliação de identidades desrespeitadas, a valorização positiva da diversidade cultural, ou a total e a completa transformação dos padrões societários de representação, interpretação e comunicação, de maneira que mudariam a identidade de todas as pessoas.

Uma breve mirada sobre a questão cultural nos mostra que a cultura indígena destoa do restante dos brasileiros, o que resulta em um estranhamento por parte da sociedade, que consequentemente os discrimina pelos seus diferentes costumes. Portanto, como bem explicitado acima, a autora propõe que uma forma de combater a injustiça é promover uma transformação cultural, ou seja, deve-se valorizar e integrar as diferentes culturas, como a dos indígenas.

Conforme o escólio de Paula (2017, p. 318):

A desejável multiplicação de etnografias sobre tais contextos de interação, se trouxerem elementos comuns para construção de um quadro comparativo e analítico, certamente contribuirão para que se avance nos debates e disputas acerca das políticas públicas. Para isso, o exame de variáveis (a serem refinadas) sobre vulnerabilidade social, pautas reivindicativas e sua relação com o marco regulatório indigenista, as próprias singularidades históricas e

Campo Jurídico|Barreiras (BA) | v.9 |e676| p.01-34 |Janeiro-Junho|2021 
socioculturais das coletividades étnicas envolvidas, dentre tantas outras possíveis, são alguns dos componentes essenciais para tal empreitada.

É com lastro nessa inferência que reiteramos a particularidade indígena quanto a sua vulnerabilidade social. Não há um grupo ou figura indígena com a devida representatividade no cenário político, e consequentemente a visibilidade de pautas reivindicatórias de direitos sociais aos indígenas são insuficientes. O escasso reconhecimento político e social dos indígenas contribui ainda mais para o perecimento cultural desse povo, resultado de sua marginalização (MATTEI; NADER, 2013).

Aqui vale a ressalva deFraser (2008, p. 179), ao sublinhar: "ver o reconhecimento como um problema de justiça é tratá-lo como uma questão de status. Isto, por sua vez, significa examinar os padrões institucionalizados de valor cultural pelos seus efeitos sobre a posição relativa dos atores sociais".

Bavaresco e Lima (2015, p. 161-2) são enfáticos ao apontar que:

O princípio da igual participação requer não só o acesso aos bens econômicos a partir da redistribuição (modelo econômico), mas também ressignificação de padrões culturais de reconhecimento que possibilite a quebra de estereótipos e preconceitos que sedimentam a exclusão de coletividades.

Em suma, conclui-se que as teorias de Nancy Fraser quanto a bivalência da justiça, das condições subjetivas e objetivas de paridade de participação e as políticas de redistribuição, em especial de reconhecimento, são pertinentemente aplicadas aos indígenas, ao passo que elas sumarizam o conceito de vulnerabilidade cultural e social de um povo para extinguir a injustiça. No mais, "se e quando tais padrões constituírem os atores como pares, capazes de participar paritariamente um com o outro na vida social, então podemos falar em reconhecimento recíproco e em igualdade de status" (FRASER, 2008, p. 179).

\section{O SISTEMA INTERNACIONAL DE DIREITOS HUMANOS APLICADO AOS INDÍGENAS}

Entende-se por Direitos Humanos os direitos essenciais que qualquer ser humano tem e que objetivam os proteger de ameaças à sua existência e dignidade. De outro giro, violar os direitos humanos significa violar a exigência moral, política e jurídica de prestar os mesmos 
direitos à todas as pessoas e de reconhecer os diferentes membros da comunidade como iguais (DEMBOUR, 2010).

Sob a luz do constitucionalismo moderno - em oposição à um regime monárquico absolutista que se preocupava principalmente com direitos civis e políticos -, os direitos humanos estão baseados no pressuposto de que todos os membros da comunidade política devem ser tratados da mesma forma perante o conteúdo da lei, traduzindo-se no princípio da isonomia (CANOTILHO, 1941; SARLET; MARINONI; MITIDIERO, 2020). Isso parte do pressuposto de que todos os indivíduos merecem o mesmo respeito e consideração, que é um fenômeno típico do Estado de Direito (HORTA, 2002). Portanto, esse principio da igualdade tem o objetivo de garantir meios para que os agentes da sociedade possam tomar decisões de forma autônoma. Porém, o mero gozo de liberdades formais não era suficiente para a promoção da emancipação humana, o que gerou diversos movimentos revolucionários. A despeito disso, começam a nascer os movimentos de internacionalização dos direitos humanos, que se materializaram em diversos tratados e declarações (GUIMARÃES, 2013).

Conforme observa Rocha (2012, p. 66): "Inquestionavelmente que a construção dos direitos fundamentais (humanos no contexto mundial) encontra-se paralelamente relacionada com a formação da democracia, através do constitucionalismo moderno".

No que tange aos povos indígenas, esse grupo conta principalmente, para a proteção de seus direitos básicos e indispensáveis, com a Carta da Organização dos Estados Americanos e o Pacto de San José da Costa Rica.

Nesse ponto, é possível sublinhar o conceito de paridade de participação, coração da teoria bivalente de justiça proposta por Nancy Fraser, como visto no tópico anterior, é de extrema importância para compreendermos o sistema internacional de Direitos Humanos. Uma vez que entendemos que as pessoas devem participar como pares na sociedade - possuindo um nível máximo de seguridade social -, deve-se, portanto, haver direitos sociais que permitam isso, consoante à uma mudança cultural das instituições para combater as diversas formas de discriminação.

A Carta da Organização dos Estados Americanos, em seu artigo 33, tem a seguinte redação:

O desenvolvimento é uma responsabilidade primordial que cada Estado deve ter, devendo, portanto, constituir um processo integral e continuo com a

Campo Jurídico|Barreiras (BA) | v.9 |e676| p.01-34 |Janeiro-Junho|2021 
finalidade de uma ordem social e econômica justa, permitindo a plena realização da pessoa humana e para isso contribua. (BRASIL, 1952).

É notório que, na vigente crise sanitária, houve uma defasagem desse princípio quando garimpeiros, grupos religiosos e invasores de terras, que muitas vezes são subordinados para adentrar território indígenas, acabam por colocar esses povos em uma situação de maior vulnerabilidade, pois estes acabam por transmitir o vírus da Covid-19 para os grupos que já estavam isolados socialmente. Com isso, o desenvolvimento mencionado no artigo supracitado acaba não sendo respeitado.

Já em seu artigo 34, a Carta da Organização dos Estados Americanos, prevê a igualdade de oportunidades, a eliminação da pobreza crítica, além de uma distribuição equitativa da riqueza e da renda. Em paralelo, é protegido o direito da plena participação dos povos nas decisões relativas a seu próprio desenvolvimento, sendo esses, objetivos básicos do desenvolvimento integral. Para a realização desses preceitos, a OEA estabeleceu metas básicas a serem seguidas, estando entre elas o aumento substancial e autossustentado do produto nacional per capita; a distribuição da renda de uma maneira equitativa; e sistemas tributários equitativos e adequados. Sendo assim, nota-se uma eminente necessidade da participação dos povos indígenas nas políticas de desenvolvimento. Também, é de extrema importância que haja a participação desses povos em decisões que concernem a políticas públicas em geral, pois, além de contribuir com uma maior representatividade, acaba por tornar mais fácil o posicionamento desses povos sobre assuntos que dizem respeito a sua própria comunidade, sendo assim, incluídos nas decisões.

O Pacto de San Jose da Costa Rica (Convenção Americana de Direitos Humanos) também possui uma relevância enorme para os direitos indígenas, sendo um tratado de direitos humanos direcionado aos Estados. Logo em seu artigo $1^{\circ}$, sobre se referir à não-discriminação, podendo ela ser de gênero, estrutural, direta e, principalmente, institucional, se referindo ao uso da discriminação dentro de cada país. Ou seja, desta forma, se faz necessária a não discriminação perante os indígenas, devendo cada país possuir uma responsabilidade interna (BRASIL, 1992).

Já em seu artigo $3^{\circ}$, no caso Sawhoyamaxa VS. Paraguai, houve o reconhecimento de personalidade jurídica à comunidade indígena. A personalidade jurídica aos indígenas não era reconhecida pela América, aplicando-se também ao Brasil. Mesmo sendo um direito adquirido por crianças desde seu nascimento com vida, não era atribuído aos índios, estes sendo 
considerados como incapazes. Com a vinda da Comissão Interamericana, os povos crenaques, guarani, yanomami, além de diversos outros, finalmente puderam adquirir seu direito de personalidade, depois de diversos processos judiciais que foram promovidos (GARCÍASAYÁN, 2010).

A Convenção Americana de Direitos Humanos, em seu artigo $5^{\circ}$, também prevê a preservação da integridade moral, psicológica e física das pessoas. A violação de direitos humanos, civis e econômicos são formas de violação da integridade psíquica, que também se configura quando o indivíduo se encontra em uma situação de vulnerabilidade permanente, sendo uma agressão a integridade física e moral dessas pessoas. Ademais, a integridade psicológica diz respeito à pessoa conseguir ser vista como uma pessoa digna (SARLET; MARINONI; MITIDIERO, 2020), se relacionando conjuntamente com o conceito da teoria de paridade de participação, da professora Nancy Fraser (FRASER, 2008). Nesse caminho, se faz necessário o respeito à integridade tanto física como psicóloga da comunidade indígena, principalmente ao que concerne na sua participação na sociedade, visando realmente serem vistos como absolutamente dignos de um cargo político, possuindo seus direitos civis respeitados, além de possuírem seu lugar de fala respeitado (APURINÃ; SCANDOLA, 2020).

Nesse diapasão, colige-se que os indígenas estão em situação de vulnerabilidade permanente, principalmente durante a crise sanitária, se tratando da transmissão do coronavírus, visto a disseminação feita por pessoas que não fazem parte de sua comunidade para os povos que já estavam em uma região isolada. Para além, há uma dificuldade do acesso ao próprio sistema de saúde por uma questão geográfica, assim, caso algum caso de emergência ocorra, muitas vezes a prestação do serviço de saúde acaba não chegando a esses povos, o que acaba por causar uma defasagem da saúde dos povos indígenas em uma plena crise sanitária (CARDOSO, 2014). Destarte, a importante observação e aplicação da legislação internacional de Direitos Humanos mostra-se mais do que necessária no presente momento quando colocamos ela em paralelo à vulnerabilidade indígena (FRUTOS, 1998, 2007, 2009).

\section{CONCLUSÃO}

Em aportes conclusivos, podemos constatar a vulnerabilidade dos povos indígenas sob o contexto histórico-político como um todo, onde sua cultura, língua e história foram severamente reprimidas desde o período colonial no Brasil. Somente a Constituição de 1988 
apresentou, de fato, um avanço na proteção dos direitos indígenas, mas não é somente com a adoção de leis que se efetivará uma condição de igualdade política e social das diversas tribos e povos indígenas.

A defasagem e a certa marginalização do grupo indígena implicou em sérias dificuldades para lidar com a atual crise sanitária do coronavírus, pois não há respeito na delimitação territorial feita para a proteção desses povos. Dessa forma, a contaminação feita por indivíduos de fora desses espaços implica em severas consequências no âmbito da saúde dos grupos indígenas, tanto pela disseminação do vírus, como pela dificuldade de acessar os hospitais por questões sociais e geográficas. A negligência do Estado representa, dessa forma, uma posição (in)direta de dar início - ou continuar - um processo de genocídio dos indígenas que desaguará na morte, não apenas física, como também social e cultural de muitas comunidades tradicionais no Brasil.

É prudente recordar que a internacionalização dos direitos humanos, figurados pelos documentos e recomendações dos comitês internacionais, representa um significativo compromisso do Estado brasileiro quanto a população indígena. Concomitantemente com a Convenção Americana sobre Direitos Humanos, a real responsabilidade do Estado em garantir a existência digna e o respeito aos direitos humanos desse grupo vulnerável se intensifica.

Bem como Nancy Fraser relata em sua obra, há uma iminente necessidade de uma política de reconhecimento, pois os indígenas já se encontram em uma situação de discrepância pelo próprio Estado e pela sociedade que impede suas atuações como atores sociais competentes, ao qual se contrapõe à ideia de paridade de participação. Com isso, faz-se necessário uma transformação cultural, com o objetivo da valorização e integração de diferentes culturas, para que assim possamos alcançar uma sociedade um pouco mais igualitária.

\section{REFERÊNCIAS BIBLIOGRÁFICAS}

ALARCON, Daniela. Povos indígenas foram vítimas de genocídio na Ditadura Militar. Adusp, São Paulo, p. 1-9, 1 nov. 2018. Disponível em: https://www.adusp.org.br/files/revistas/62/02.pdf. Acesso em: 29 set. 2020.

ALCÂNTARA, Gustavo Kenner; MAIA, Luciano Mariz; TINÔCO, Lívia Nascimento. Índios, direitos originários e territorialidade. Brasília: Editora ANPR, 2018. 
ALMEIDA, Carina dos Santos. Tempo, memória, e narrativa Kaingang no oeste catarinense. 2015. Florianópolis-SC: Universidade Federal de Santa Catarina, 2015. 542 f. Tese (doutorado) - Universidade Federal de Santa Catarina. Florianópolis-SC, 2015.

ALMEIDA, Silvio Luiz de. Racismo Estrutural. São Paulo: Polén, 2019.

APURINÃ, Kuawa; SCANDOLA, Estela Rondina. Povos indígenas no Brasil: direitos, políticas sociais e resistências. Porto Alegre: Nova Práxis Editorial, 2020.

BARRETO, Helder Girão. Direitos indígenas: vetores constitucionais. Curitiba: Juruá Editora, 2003.

BAVARESCO, Agemir; LIMA, Francisco Jozivan Guedes de. Saúde e Conflitos de Interesses a partir da Bidimensionalidade da Justiça e da Paridade de Participação de Nancy Fraser. Revista Opinião Filosófica, Porto Alegre, v. 6, n. 2, p. 149-163, 2015. Disponível em: https://opiniaofilosofica.org/index.php/opiniaofilosofica/article/view/670. Acesso em: 26 out. 2020.

BERGSTRAND, Kelly et al. Assessing the relationship between social vulnerability and community resilience to hazards. Social indicators research, v. 122, n. 2, p. 391-409, 2015.

BOLETIM EPIDEMIOLÓGICO DA SESAI. Ministério da Saúde, Brasília, DF. Disponível em: https://saudeindigena.saude.gov.br/corona. Acesso em: 30 set. 2020.

BRASIL, Kátia; FARIAS, Elaíze. Comissão da Verdade: Ao menos 8,3 mil índios foram mortos na ditadura militar. Amazônia Real, [S. l.], p. 1-2, 11 dez. 2014. Disponível em: https://amazoniareal.com.br/comissao-da-verdade-ao-menos-83-mil-ind ios-foram-mortos-naditadura-militar/. Acesso em: 29 set. 2020.

BRASIL. Constituição (1988). Constituição da República Federativa do Brasil. Brasília, DF: Senado Federal: Centro Gráfico, 1988.

BRASIL. Decreto ${ }^{\circ}$ 30.544, de 14 de fevereiro de 1952. Promulga a Carta da Organização dos Estados Americanos, firmad a em Bogotá, a 30 de abril de 1948. Diário Oficial da União, Seção 1 - 19/2/1952, p. 2473. Disponível em: https://www2.camara.leg.br/legin/fed/decret/1950 1959/decreto-30544-14-fevereiro-1952-340000-publicacaooriginal-1-pe.html. Acesso em: 04 nov. 2020.

BRASIL. Decreto n ${ }^{\circ}$ 678, de 6 de novembro de 1992. Promulga o texto da Convenção Americana sobre Direitos Humanos (Pacto de São José da Costa Rica). Diário Oficial da União, Brasília, DF: Presidência da República. Disponível em: https://www.planalto.gov.br/ccivil_03/decreto/d0678.htm. Acesso em: 04 nov. 2020.

BRASIL. Lei n ${ }^{\circ}$ 6.001, de 19 de dez de 1973. Dispõe sobre o Estatuto do índio e dá outras providências. Diário Oficial da República Federativa do Brasil, Brasília, DF, 19 dez. 1973. Disponível em: <http://www.planalto.gov.br/ccivil_03/Leis/L6001.htm>. Acesso em: 30 set. 2020.

Campo Jurídico|Barreiras (BA) | v.9 |e676| p.01-34 |Janeiro-Junho|2021 
BRASIL. Supremo Tribunal Federal. Arguição de Descumprimento de Preceito Fundamental 709. Relator: Ministro Roberto Barroso. Brasília, DF, 05 ago. 2020. Disponível em: http://redir.stf.jus.br/paginadorpub/paginad or.jsp?d ocTP=TP\&docID=754033962. Acesso em: 31 out. 2020.

CANOTILHO, José Joaquim Gomes. Direito Constitucional e Teoria da Constituição. 7a ed., 13a reimpressão. Coimbra: Edições Almedina, 1941.

CARDIN, Valéria Silva Galdino; CRUZ, Mariana Franco. Os direitos da personalidade no Direito brasileiro: do fenômeno de personalização à cláusula geral de direito da personalidade. Revista do Direito Público, Londrina, v. 15, n. 2, p. 10-26, ago. 2020.

CARDOSO, Mariana Denise. Saúde e povos indígenas no Brasil: notas sobre alguns temas equívocos na política atual. Cad. Saúde Pública [online], São Paulo, v.30, n.4, p.860-866, $2014 . \quad$ Disponível em: https://www.scielo.br/j/csp/a/R7GRfRXh8Vg7LKr46wN8Wbd/abstract/?lang=pt. Acesso em 8 jul. 2021.

CARMO, Cláudio Márcio do. Grupos minoritários, grupos vulneráveis e o problema da (in)tolerância: uma relação linguístico-discursiva e ideológica entre o desrespeito e a manifestação do ódio no contexto brasileiro. Revista do Instituto de Estudos Brasileiros, n. 64, p. 201-223, 23 ago. 2016.

CARVALHO, Alba Maria Pinho de. Radicalizar a Democracia: O desafio da reinvenção da política em tempos de ajuste, Revista Políticas Públicas, São Luís, v.1, n.1, 2004. Disponível em: http://www.periodicoseletronicos.ufma.br/index.php/rppublica/article/view/3757. Acesso em: 29 set. 2020.

CASTRO, Eduardo Viveiros de. Quem são? Povos Indígenas no Brasil, [S. l.], p. 1-6, 5 jun. 2018. Disponível em: https://pib.socioambiental.org/pt/Quem_s\%C3\%A3o. Acesso em: 29 set. 2020.

CUNHA, Manuela Carneiro da; BARBOSA, Samuel. Direitos dos povos indígenas em disputa. São Paulo: Editora UNESP, 2018.

DEMBOUR, Marie-Bénédicte. What Are Human Rights? Four Schools of Thought. Human Rights Quarterly, v. 32, n. 1, p. 1-20, fev. 2010.

DHILLON, Jaskiran. Introduction: Indigenous resurgence, decolonization, and movements for environmental justice. Environment and Society, v. 9, n. 1, p. 1-5, 2018.

DORNELLES, Ederson Nadir Pires; VERONESE, Osmar. A falta de representatividade indígena nos parlamentos brasileiros: a democracia representativa vigente deve ser (re)inventada? Revista Eletrônica Direito e Política, Itajaí, v.13, n.1, 2018. Disponível em: https://siaiap32.univali.br/seer/index.php/rdp/article/view/12619. Acesso em: 29 set. 2020.

FRASER, Nancy. Redistribuição, Reconhecimento e Participação: por uma concepção integrada da justiça. Trad. Bruno Ribeiro e Letícia de Campos Velho. In: IKAWA, Daniela;

Campo Jurídico|Barreiras (BA) | v.9 |e676| p.01-34 |Janeiro-Junho|2021 
PIOVESAN, Flávia; SARMENTO, Daniel (coord.). Igualdade, Diferença e Direitos Humanos. Lumen Juris: Rio de Janeiro: 2008.

FRUTOS, Juan Antonio Senent de. Ecología y problemas medioambientales. Orientaciones para la praxis desde otro marco cultural. Revista de fomento social, La paz, n. 256, p. 699708, 2009.

FRUTOS, Juan Antonio Senent de. Ellacuría y los derechos humanos. Bilbao: Desclée de Brouwer, 1998.

FRUTOS, Juan Antonio Senent de. Problemas fundamentales de los derechos humanos desde el horizonte de la praxis. Valencia: Tirant lo Blanch, 2007.

FUNAI. Povos indígenas isolados e de recente contato, [S. l.], p. 1-2, 29 set. 2020. Disponível em: http://www.funai.gov.br/index.php/nossas-acoes/povos-indigenas-isolados-e-de-recentecontato?start=1\#. Acesso em: 29 set. 2020.

GALEANO, Eduardo. As veias abertas da América Latina. São Paulo: L\&PM, 2010.

GARCÍA-SAYÁN, Diego, 2010. Voto concorrente no caso: Comunidade Indígena Xákmok Kásek vs. Paraguai. Sentença CIDH de 24 de agosto de 2010. Disponível em: https://www.corteidh.or.cr/docs/casos/articulos/seriec_214_por.pdf. Acesso em: 04 nov. 2020.

GARFIELD, Seth. As raízes de uma planta que hoje é o Brasil: os índios e o Estado-Nação na era Vargas. Rev. bras. Hist., São Paulo, v. 20, n. 39, p. 13-36, 2000. Disponível em: http://www.scielo.br/scielo.php?script=sci_arttext\&pid=S0102-

$01882000000100002 \& \operatorname{lng}=$ pt\&nrm=iso. Acesso em: 28 out. 2020.

GOIS, Daniel; BRUNO, Gabriel. Líderes indígenas culpam preconceito por aumento do número de suicídios: Números são superiores aos de assassinatos e atingem mais faixa etária até 29 anos. G1, [S. l.], p. 1-25, 23 nov. 2019. Disponível em: https://g1.globo.com/sp/santosregiao/educacao/noticia/2019/11/23/lideres-indigenas-culpam-preconceito-por-aumento-donumero-de-suicidios.ghtml. Acesso em: 30 out. 2020.

GONZAGA, Alvaro de Azevedo. Decolonialismo indígena. São Paulo: Matrioska, 2021.

GOODALE, Mark. Toward a critical anthropology of human rights. Current anthropology, Chicago, v. 47, n. 3, p. 485-511, 2006.

GUIMARÃES, Débora Soares. A internacionalização dos Direitos Humanos: análise da proposta liberal universalizante. Revista CEJ, Brasília, Ano XVII, n. 59, p. 125-137, jan./abr., 2013.

HORTA, José Luiz Borges. Horizontes Jusfilosóficos do Estado de Direito: Uma investigação tridimensional do Estado liberal, do Estado social e do Estado democrático, na perspectiva dos Direitos Fundamentais. Belo Horizonte: Faculdade de Direito daUFMG, 2002. (Tese, Doutorado em Filosofia do Direito). Disponível em: http://hdl.handle.net/1843/BUBD96KQMD. Acesso em: 03 nov. 2020.

Campo Jurídico|Barreiras (BA) | v.9 |e676| p.01-34 |Janeiro-Junho|2021 
LOBO, Luiz Felipe Bruno. Direito indigenista brasileiro: subsídios à sua doutrina. São Paulo: Editora LTr, 1996.

LOPES, Aline Luciane; CORRÊA, Darcísio. O multiculturalismo e os direitos fundamentais dos povos indígenas: a luta pela igualdade no Brasil da intolerância. Rev. Ciên. Jur. e Soc. da Unipar, Umuarama, v. 11, n. 2, p. 471-489, jul./dez. 2008. Disponível em: https://revistas.unipar.br/index.php/juridica/article/view/2762. Acesso em: 30 set. 2020.

MANTELLI, Gabriel Antonio Silveira; ALMEIDA, Julia de Moraes. Saberes descoloniais, práticas socioambientais: uma reflexão sobre o Conselho Nacional de Povos e Comunidades Tradicionais. In: BRITO, Ciro de Souza. Direitos dos povos e comunidades tradicionais e povos indígenas em contextos de retrocessos. Curitiba: Editora CRV, 2019. p. 177-193.

MARÉS DE SOUZA FILHO, Carlos Frederico. O renascer dos povos indígenas para o direito. Curitiba: Juruá, 1998.

MATTEI, Ugo; NADER, Laura. Pilhagem: quando o Estado de Direito é ilegal. São Paulo: Martins Fontes, 2013.

MCLAREN, Peter. Multiculturalismo crítico. São Paulo: Cortez Editora, 1997.

MOREIRA, Adilson José; CALFAT NETO, João Demétrio. O que é discriminação?. São Paulo, 2016 (manuscrito).

MOREIRA, Adilson José. Direitos Fundamentais como Estratégias Anti-hegemônicas: Um Estudo sobre a Multidimensionalidade de Opressões. Revista Quaestio Iuris, Rio de Janeiro, v. $9, \quad$ n. $3, \quad$ p. 1559-1599, 2016. Disponível em: https://www.epublicacoes.uerj.br/index.php/quaestioiuris/article/view/20235. Acesso em: 29 set. 2020.

MOREIRA, Adilson José. Tratado de direito antidiscriminatório. São Paulo: Editora Contracorrente, 2020.

MOREIRA, Adilson. Racismo recreativo. São Paulo: Pólen, 2019.

OLIVÉ, León. Multiculturalismo y pluralismo. México: Paidós, 1999.

OLIVEIRA FILHO, João Pacheco de. Cidadania e globalização: povos indígenas e agências multilaterais. Horizontes antropológicos, Porto Alegre, v. 6, p. 125-141, 2000.

OVIEDO, Rafael Antônio Malagón; CZERESNIA, Dina. O conceito de vulnerabilidade e seu caráter biossocial. Interface - Comunicação, Saúde, Educação [online], Botucatu, v. 19, n. 53 p. 237-250, 2015 Disponível em: https://www.scielosp.org/article/icse/2015.v19n53/237250\#ModalArticles. Acesso em: 30 set. 2020.

Campo Jurídico|Barreiras (BA) | v.9 |e676| p.01-34 |Janeiro-Junho|2021 
PARAISO, Maria Hilda B. Construindo o estado da exclusão: os índios brasileiros e a constituição de 1824. Revista CLIO - Revista de Pesquisa Histórica, Pernambuco, v. 28, n. 2, p. 1-17, 5 jan. 2010.

PAULA, Luis Roberto de. Afirmação de direitos indígenas em contextos ampliados de interação social: referências bibliográficas e alguns problemas de investigação. ARACÊDireitos Humanos em Revista, São Paulo, v. 4, n. 5, p. 295-322, 2017. Disponível em: https://arace.emnuvens.com.br/arace/article/view/146. Acesso em: 26 set. 2020.

PIOVESAN, Flavia. Ações afirmativas da perspectiva dos direitos humanos. Cadernos de pesquisa, São Paulo, v. 35, p. 43-55, 2005.

PONTES, Ana Lucia; et al.. Vulnerabilidades, impactos e o enfrentamento ao Covid-19 no contexto dos povos indígenas: reflexões para a ação. Observatório Covid-19 Fiocruz, Rio de Janeiro, 2020. Disponível em: https://www .arca.fiocruz.br/handle/icict/41196. Acesso em: 26. set. 2020.

PRESTES, Fabiane da Silva; et al. A questão indígena no Brasil: um olhar a partir do entrelaçamento entre história e direito. Âmbito Jurídico, [S. l.], p. 1-2, 2017. Disponível em: https://ambitojuridico.com.br/cadernos/direitos-humanos/a-questao-indigena-no-brasil-umolhar-a-partir-do-entrelacamento-entre-historia-e-direito/. Acesso em: 28 set. 2020.

RIOS, Roger Raupp. Direito da antidiscriminação: discriminação direta, indireta e ações afirmativas. Porto Alegre: Livraria do Advogado Editora, 2008.

ROCHA, Cláudio Jannotti da. O constitucionalismo, a democracia e os direitos fundamentais trabalhistas. Quaestio Iuris, Rio de Janeiro, v. 5, n. 2, p. 57-84, 2012. DOI http://dx.doi.org/10.12957/rqi.2012.9873. Disponível em: https://www.epublicacoes.uerj.br/index.php/quaestioiuris/article/view/9873. Acesso em: 04 nov. 2020.

ROCHA, Diogo Ferreira da; PORTO, Marcelo Firpo de Souza; PACHECO, Tania. A luta dos povos indígenas por saúde em contextos de conflitos ambientais no Brasil (1999-2014). Ciência \& Saúde Coletiva, v. 24, p. 383-392, 2019. Disponível em: https://www.scielo.br/j/csc/a/dSgZJn5NWyKx65vqHDQXfBN/?format=html\&lang=pt\#.

Acesso em 8 jul. 2021.

RODRÍGUEZ, Virgilio Ruiz. Discriminación: negacion de la persona. Cidade do México: EditorialPorrúa, 2016.

ROGERS, Wendy; BALLANTYNE, Angela. Populações especiais: vulnerabilidade e proteção. RECIIS - R. Eletr. de Com. Inf. Inov. Saúde, Rio de Janeiro, v. 2, p. 31-41, dez. 2008. Disponível em: https://www.reciis.icict.fiocruz.br/index.php/reciis/article/view/865. Acesso em: 29 set. 2020.

ROSHA, J. Indígenas temem proliferação de coronavírus com entrada ilegal de evangélicos na TI Vale do Javari: A Univaja denuncia que são missionários evangélicos dos EUA. Um deles já entrou na área outras vezes sem comunicar as lideranças e a Funai. Conselho indigenista missionário, [S. 1.], p. 1-6, 24 mar. 2020. Disponível em: 
https://cimi.org.br/2020/03/indigenas-temem-proliferacao-de-coronavirus-com-entrada-ilegalde-evangelicos-na-ti-vale-do-javari/. Acesso em: 31 out. 2020.

SANTOS FILHO, Roberto Lemos dos. Apontamentos sobre o direito indigenista. Curitiba: Juruá Editora, 2005.

SARLET, Ingo Wolfgang; MARINONI, Luiz Guilherme; MITIDIERO, Daniel. Curso de direito constitucional. São Paulo: Saraiva, Educação, 2020.

SCHREIBER, Mariana. Por que Bolsonaro está sendo acusado de colocar indígenas em risco em meio à pandemia de covid-19: Enquanto a pandemia do coronavírus avança pelo interior do país, lideranças indígenas acusam o presidente Jair Bolsonaro de não ter tomado as medidas emergenciais necessárias para proteger seus povos da covid-19. BBC News Brasil, [S. l.], p. 113, 11 jul. 2020. Disponível em: https://www.bbc.com/portuguese/brasil-53375095. Acesso em: 30 out. 2020.

SÉGUIN, Elida. Minorias e grupos vulneráveis: uma abordagem jurídica. Rio de Janeiro: Forense, 2002.

SILVA, Elizângela Cardoso de Araújo. Povos indígenas e o direito à terra na realidade brasileira. Serv. Soc. Soc., São Paulo, n. 133, p. 480-500, Dez. 2018. Disponível em: http://www.scielo.br/scielo.php?script=sci_arttext\&pid=S010166282018000300480\&lng=en $\& n r m=i s o$. Acesso em: 30 set. 2020.

SILVA, Paulo Thadeu Gomes da. Os direitos dos índios: fundamentalidade, paradoxos e colonialidades internas. 2. ed. Belo Horizonte: Editora Fórum, 2021.

SODRÉ, Muniz. Por um conceito de minoria. In: PAIVA, Raquel; BARBALHO, Alexand re. (Orgs.). Comunicação e cultura das minorias. São Paulo: Paulus, 2005.

STREIT, Maíra. 35 anos depois do deputado Juruna, indígenas continuam sem representação política no país: Segundo TSE, candidatos indígenas correspondem a apenas $0,34 \%$ do total; preconceito da sociedade e falta de apoio financeiro estão entre os motivos da baixa participação. [S. l.], 25 abr. 2018. Disponível em: https://apublica.org/2018/04/35-anosdepois-do-deputado-juruna-indigenas-continuam-sem-representacao-politica-no-pais/. Acesso em: 30 set. 2020.

SZANIAWISKI, Elimar. Direitos da personalidade e sua tutela. 2. ed. São Paulo: Revista dos Tribunais, 2005.

TUCK, Eve; YANG, K. Wayne. Decolonization is not a metaphor. Decolonization: Indigeneity, Education \& society, v. 1, n. 1, p. 1-40, 2012.

VALENTE, Rubens. Os fuzis e as flechas: história de sangue e resistência indígena na ditadura. São Paulo: Companhia das Letras, 2017.

VERSOLATO, Fernanda; GOMES, Maria Judith Magalhães (Coord.). Direito dos povos e comunidades tradicionais em territórios protegidos. São Paulo: Instituto Pólis, 2016. 
VIEIRA, Hugo Otavio Tavares. As Ordenações Filipinas: o DNA do Brasil. Revista dos Tribunais, São Paulo, v. 958, p. 1-7, 2015. Disponível em: http://www.mpsp.mp.br/portal/page/portal/documentacao_e_divulgacao/doc_biblioteca/bibli_ servicos_produtos/bibli_boletim/bibli_bol_2006/RTrib_n.958.12.PDF. Acesso em: 28 set. 2020.

VILLARES, Luiz Fernando. Direito e povos indígenas. Curitiba: Juruá, 2009.

WILL, Karhen Lola Porfirio. Genocídio Indígena no Brasil. Tese (Dissertação de Mestrado). Universidade de Coimbra, 2014. Disponível em: https://estudogeral.uc.pt/bitstream/10316/28713/1/Genocidio\%20indigena\%20no\%20Brasil.p df. Acesso em: 27 set. 2020. 